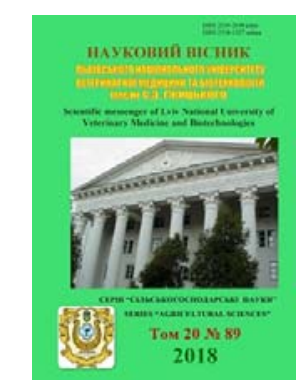

UDC 636.03: 636.5

\section{Науковий вісник Дьвівського національного університету ветеринарної медицини та біотехнологій імені С.3. Гжицького}

\author{
Scientific Messenger of Lviv National University \\ of Veterinary Medicine and Biotechnologies
}

ISSN 2519-2698 print

doi: $10.32718 /$ nvlvet8918

ISSN 2518-1327 online

\title{
Activity of hydrolytic enzyme in the poultry of different species
}

\author{
B.Ya. Kyryliv, A.V. Hunchak, O.M. Stefanyshyn \\ Institute of Animal Biology of NAAS, Lviv, Ukraine
}

Article info

Received 17.09.2018

Received in revised form 18.10 .2018

Accepted 19.10.2018

Institute of Animal Biology of NAAS, V. Stusa Str., 38, Lviv, 79000, Ukraine.

Tel.: +38-068-185-63-48

E-mail:kyryliv@ukr.net
Kyryliv, B.Ya., Hunchak, A.V., \& Stefanyshyn, O.M. (2018). Activity of hydrolytic enzyme in the poultry of different species. Scientific Messenger of Lviv National University of Veterinary Medicine and Biotechnologies, 20(89), 95-99. doi: 10.32718/nvlvet8918

In the processes of digestion and assimilation of nutrients of feed in the body a special place belongs to the digestive system. Hydrolysis of nutrients in the gastrointestinal tract of farm poultry is closely linked to its physiological state, the intensity of metabolic processes in the body and its productivity. However, there are no significant differences in the course and regulation of digestive functions between individual poultry species. At the same time, for different types of poultry, certain distinctive patterns of the course of digestive processes and, in particular, the activity of hydrolytic enzymes, due to the peculiarities of the structure and functioning of the digestive system, are characteristic. In the article is given a fragment of complex systemic researches, which is concerning the proteolytic, amylolytic and lipolytic activity of enzymes in tissues of the organs of the digestive canal (mucous membrane of the glandular and duodenum, pancreas, liver) of the quail breed "Pharaoh", as well as chicken egg productivity direction cross "Hayseks Brown" and the Beijing Broiler Duck Cross STAR 53 (heavy) selection of the French firm "GRIMAUD FRERES SELECTION" during the critical periods of their growth and development. Namely, in the period of adaptation of the organism after hatching (day-old chicks of all species), complete resorption of residual yolk (7-day quail and 6-day chickens and ducks) and puberty (120-day chickens, 42-day quails, 180-daily ducks) All poultry was kept in poultry farms and received balanced full-fodder feeds, taking into account its species, age and physiological condition. The technology of keeping quails and chickens in cellular batteries, and ducks - on the mesh floor, with free access to the feed and water. It was established, that the nature of changes in the activity of hydrolytic enzymes had organ-tissue and species specificity. This is due not only to the particularities of digestion in quails, chickens and ducks, but also the energy value of rations used in feeding each type of farm poultry, which significantly affects metabolic processes in the body.

Key words: chickens, quails, ducks, proteolytic, amylolytic and lipolytic activity.

\section{Активність гідролітичних ензимів у птиці різних видів}

\author{
Б.Я. Кирилів, А.В. Гунчак, О.М. Стефанишин
}

Інститут біологї тварин НААН, м. Львів, Україна

\footnotetext{
У прочесах розщеплення $і$ засвоєння поживних речовин кормів в організмі особливе місие належить системі травлення. Гідроліз нутрієнтів у травному каналі сільськогосподарської птиці тісно пов 'язаний з ї̈ фізіологічним станом, інтенсивністю метаболічних процесів в організмі та продуктивністю. При иьому, суттєвих відмінностей перебігу та регуляції травних функцій між окремими видами птахів не існує. Водночас, для птиџі різних видів характерними є певні відмінні закономірності перебігу травних процесів $i$, зокрема, активності гідролітичних ензимів, що обумовлено особливостями будови і функціонування травної системи. $У$ статті наведено фрагмент комплексних системних досліджень, що стосується протеолітичної, амілолітичної та ліполітичноі активності ензимів в тканинах органів травного каналу (слизова оболонка залозистого шилуночка та дванадиятипалої кишки, підилункова залоза, печінка) перепілок породи “Фараон”, а також курей яєчного напряму продуктивності кросу “Хайсекс Коричневий” і пекінської бройлерної качки кросу STAR 53 (важкий) селекиї̈ франиузької фірми “GRIMAUD FRERES SELECTION” y критичні періоди їх росту та розвитку. А саме, у період адаптаиії організму після вилуплення (добові птаменята всіх видів), повного розсмоктування залишкового жовтка (7-добові перепілки і 6-добові кури і качки) та статевої зрілості (120-добові кури, 42добові перепілки, 180-добові качки). Вся птиця утримувалась в умовах птахівничих господарств і отримувала збалансовані повнораціонні комбікорми, з урахуванням їі виду, віку та фізіологічного стану. Технологія утримання перепілок та курей - у кліткових батареях, а качок - на сітчастій підлозі, з вільним доступом до корму і води. Встановлено, що характер змін активності гідролітичних ензимів мав органо-тканинну та видову специфічність. Це зумовлено не лише особливостями травлення у перепілок, курей
} 
та качок, але й енергетичною иінністю раціонів, які використовуються у годівлі кожного виду сільськогосподарської птиці, щчо суттєво впливає на метаболічні процеси в організмі.

Ключові слова: кури, перепілки, качки, протеолітична активність, амілолітична активність, ліполітична активність.

Вступ

Одним 3 ключових чинників, який впливає на життєво важливі функції в організмі птиці, є процеси травлення і засвоєння поживних речовин у шлунковокишковому тракті. Функціонування травної системи $\epsilon$ результатом добре скоординованих і взаємозв'язаних реакцій різних органів. Хоч у перебігу та регуляції травних функцій суттєвих відмінностей між окремими видами птахів не існує (Naumenko et al., 2009; Hunchak et al., 2016; Medvid et al., 2017), проте, будова і функціонування травної системи птиці мають свої особливості (Batoev, 2011; Kyryliv and Hunchak, 2016), які по різному впливають на інтенсивність обмінних процесів, ріст, розвиток та продуктивність. При цьому, удосконалення рецептури комбікормів і прогнозування здатності птиці кожного віку перетравлювати запропонований корм не можливе без розуміння реальних особливостей травлення, які, перш за все, визначаються складом гідролітичних ензимів та їх активністю (Vladimír et al., 2010). Дослідження активності гідролітичних ферментів у взаємозв'язку з показниками продуктивності, до певної міри, може свідчити про інтенсивність процесів травлення та засвоєння поживних речовин корму.

Проміжні етапи розщеплення необхідних поживних речовин корму в організмі птиці відбуваються за участі ензимів, абсорбованих на слизовій органів травного каналу. Слизова оболонка всіх порожнинних органів в організмі є типовою і представляє собою поверхневу частину стінки, покритої слизом, секретованим епітеліоцитами, які вистилають внутрішні поверхні органів травлення. Слиз сприяє проходженню їжі по травному каналу, і виконує захисну функцію стінок органів від хімічних, механічних подразників, а також від процесу самоперетравлювання, зволожуючи поверхневий шар порожнин (Kharchenko, 2004).

Водночас, гідроліз нутрієнтів у травному каналі птиці тісно пов'язаний з її фізіологічним станом, інтенсивністю метаболічних процесів в організмі та продуктивністю. 3 даних літератури відомо, що існують певні особливості процесів травлення у різних видів птахів (Fisinin and Egorov, 2011; Kyryliv and Hunchak, 2016; Kryshtalska et al., 2017; Kyryliv, 2018). У той же час мало інформації, яка б стосувалась активності гідролітичних ензимів у різних видів птахів у періоди адаптації після вилуплення 3 яйця, повного розсмоктування залишкового жовтка та яйцекладки у порівняльному аспекті.

\section{Матеріал і методи досліджень}

Дослідження проведено на перепілках породи “Фараон”, а також курях яєчного напряму продуктивності кросу “Хайсекс Коричневий” і пекінській бройлерній качці кросу STAR 53 (важкий) селекції французької фірми GRIMAUD FRERES SELECTION y виробничих умовах ферм. Птиця споживала повнораціонні комбікорм (ПРК), збалансовані за поживними і біологічно активними компонентами, відповідно до нормування годівлі для кожного з видів птиці.

У критичні періоди росту і розвитку птиці, а саме у період адаптації після вилуплення (добові пташенята), повного розсмоктування залишкового жовтка (7добові перепілки та 6-добові кури і качки) й статевої зрілості (120-добові кури, 42-добові перепілки, 180добові качки), відібрано біологічний матеріал для визначення протеолітичної, амілолітичної та ліполітичної активності ензимів у тканинах органів травного каналу (Vlizlo et al., 2012).

\section{Результати та їх обговорення}

Результати проведених досліджень (табл. 1) свідчать про те, що, у слизовій оболонці шлунка протеолітична активність, порівняно з показниками у перепілок і качок, була найвищою в курчат у період адаптації після їх вилуплення та на завершення повного розсмоктування залишкового жовтка.

\section{Таблиця 1}

Видові особливості активності гідролітичних ензимів слизової оболонки залозистого шлуночка, $(\mathrm{M} \pm \mathrm{m}, \mathrm{n}=5)$

\begin{tabular}{|c|c|c|c|}
\hline Фізіологічний період & Кури & Перепілки & Качки \\
\hline \multicolumn{4}{|c|}{ Протеолітична активність, мкат/г.б. } \\
\hline Після вилуплення & $25,82 \pm 1,13$ & $17,24 \pm 1,12$ & $2,34 \pm 0,32$ \\
\hline Розсмоктування залишкового жовтка & $29,68 \pm 0,68$ & $18,37 \pm 1,07$ & $4,34 \pm 0,31$ \\
\hline Статевої зрілості & $5,26 \pm 0,38$ & $15,21 \pm 0,74$ & $3,97 \pm 0,49$ \\
\hline \multicolumn{4}{|c|}{ Амілолітична активність, од.акт/хв ${ }^{\times}$г.б. } \\
\hline Адаптації після вилуплення & $1,23 \pm 0,22$ & $6,18 \pm 0,57$ & $14,94 \pm 0,86$ \\
\hline Розсмоктування залишкового жовтка & $5,31 \pm 0,56$ & $8,23 \pm 0,43$ & $10,91 \pm 0,66$ \\
\hline Статевої зрілості & $3,08 \pm 0,56$ & $7,98 \pm 0,23$ & $11,96 \pm 0,53$ \\
\hline \multicolumn{4}{|c|}{ Ліполітична активність, од.акт/г.тк } \\
\hline Адаптації після вилуплення & $1,34 \pm 0,18$ & $11,38 \pm 0,65$ & $34,45 \pm 1,89$ \\
\hline Розсмоктування залишкового жовтка & $3,37 \pm 0,54$ & $7,25 \pm 0,37$ & $33,57 \pm 1,65$ \\
\hline Статевої зрілості & $3,57 \pm 0,58$ & $11,59 \pm 0,61$ & $30,86 \pm 1,31$ \\
\hline
\end{tabular}


Щодо амілолітичної та ліполітичної активності, то перевага була на користь качок. Характер зміни активності цих ензимів у досліджуваних тканинах був подібним і знижувався в такій послідовності: качки, перепілки, кури.

Процес перетравлення протікає, головним чином, у дванадцятипалій кишці за рахунок ензимів, що виділяються підшлунковою залозою, а також самим кишечником та жовчю, що виробляється печінкою. Зауважимо, що аналогічно до показників у слизовій залозистого шлуночка, протеолітична активність слизової оболонки дванадцятипалої кишки (табл. 2) також була вищою у перепелів, порівняно 3 курми та качками, в усі досліджувані фізіологічні періоди росту і розвитку птиці.

А саме: у перепілок у період адаптації після вилуплення активність була вищою в 3,2 раза, ніж у курей та в 1,7, ніж у качок; у період повного розсмоктування залишкового жовтка, відповідно, у 3,5 та 2,4 раза, а в період статевої зрілості - у 3,4 та 2,9.

\section{Таблиця 2}

Видові особливості активності гідролітичних ензимів слизової оболонки дванадцятипалої кишки, $(\mathrm{M} \pm \mathrm{m}, \mathrm{n}=5)$

\begin{tabular}{|c|c|c|c|}
\hline Фізіологічний період & Кури & Перепілки & Качки \\
\hline \multicolumn{4}{|c|}{ Протеолітична активність, мкат/г.б. } \\
\hline Адаптації після вилуплення & $2,93 \pm 0,24$ & $9,43 \pm 0,56$ & $5,54 \pm 0,54$ \\
\hline Розсмоктування залишкового жовтка & $4,03 \pm 0,23$ & $14,55 \pm 0,63$ & $5,97 \pm 0,43$ \\
\hline Статевої зрілості & $3,47 \pm 0,15$ & $11,69 \pm 0,87$ & $4,05 \pm 0,31$ \\
\hline \multicolumn{4}{|c|}{ Амілолітична активність, од.акт/хв×г.білка } \\
\hline Адаптації після вилуплення & $2,91 \pm 0,17$ & $4,77 \pm 0,33$ & $2,57 \pm 0,11$ \\
\hline Розсмоктування залишкового жовтка & $3,19 \pm 0,38$ & $5,94 \pm 0,28$ & $3,64 \pm 0,21$ \\
\hline Статевої зрілості & $2,40 \pm 0,12$ & $6,28 \pm 0,57$ & $2,48 \pm 0,16$ \\
\hline \multicolumn{4}{|c|}{ Ліполітична активність, од.акт/г.тк } \\
\hline Адаптації після вилуплення & $2,23 \pm 0,11$ & $17,15 \pm 1,05$ & $16,03 \pm 1,11$ \\
\hline Розсмоктування залишкового жовтка & $10,18 \pm 0,32$ & $39,24 \pm 1,75$ & $14,22 \pm 0,81$ \\
\hline Статевої зрілості & $13,02 \pm 0,41$ & $30,76 \pm 1,49$ & $16,99 \pm 0,43$ \\
\hline
\end{tabular}

Тенденція зміни амілолітичної активності у цих тканинах також була подібною. Проте, міжвидова різниця активності цих ензимів була меншою, ніж активності протеаз. Загалом, амілолітична активність слизової оболонки дванадцятипалої кишки була, приблизно, на одному рівні у курей та качок та, порівняно, вищою у перепілок.

Найнижчу ліполітичну активність слизової оболонки дванадцятипалої кишки пташенят у період адаптації після вилуплення встановлено у молодняку курей. При цьому, у перепелят та каченят вона була у 8 разів вищою. У наступні досліджувані вікові періоди активність ензиму була максимально високою у перепелів i, порівняно, нижчою та приблизно однаковою у курей та качок.

Підшлункова залоза - основний орган утворення та виділення травних ензимів. Регуляція ii секреції здійснюється нервовими і гуморальними механізма- ми, а функціональна діяльність зростає більшою мірою за рахунок активності наявних гідролітичних ферментів, ніж за рахунок збільшення об'єму секрету. При цьому, підшлункова залоза тонко і адекватно реагує на зміни структури раціону зміною секреції соку і всіх його ензимних груп. Відзначено здатність залози, як до термінової, так і до довготривалої адаптації за тривалого утриманні птиці на певному раціоні. Знижена концентрація протеїну в раціоні викликає стабільне зниження функції залози. Збільшення вмісту протеїну і вуглеводів в складі раціону викликає збільшення зовнішньосекреторної функції залози.

У наших дослідженнях встановлено певні відмінності активності гідролітичних ензимів у тканинах підшлункової залози різних видів птиці (табл. 3). Зокрема, протеолітична активність у курчат, у період їх адаптації після вилуплення, була найнижчою, порівняно з іншими досліджуваними видами.

Таблиця 3

Видові особливості активності гідролітичних ензимів підшлункової залози, $(\mathrm{M} \pm \mathrm{m}, \mathrm{n}=5)$

\begin{tabular}{|c|c|c|c|}
\hline Фізіологічний період & Кури & Перепілки & Качки \\
\hline \multicolumn{4}{|c|}{ Протеолітична активність, мкат/г.б. } \\
\hline Адаптації після вилуплення & $13,43 \pm 1,93$ & $24,97 \pm 1,01$ & $121,19 \pm 1,82$ \\
\hline Розсмоктування залишкового жовтка & $48,45 \pm 3,33$ & $28,23 \pm 1,23$ & $134,69 \pm 2,60$ \\
\hline Статевої зрілості & $134,13 \pm 1,98$ & $46,17 \pm 0,98$ & $81,21 \pm 1,79$ \\
\hline \multicolumn{4}{|c|}{ Амілолітична активність, од.акт/хв×г.б. } \\
\hline Адаптації після вилуплення & $2,63 \pm 0,67$ & $10,95 \pm 0,65$ & $9,14 \pm 1,01$ \\
\hline Розсмоктування залишкового жовтка & $14,04 \pm 0,77$ & $12,05 \pm 0,87$ & $8,84 \pm 0,75$ \\
\hline Статевої зрілості & $14,42 \pm 0,75$ & $9,06 \pm 0,73$ & $6,45 \pm 0,52$ \\
\hline \multicolumn{4}{|c|}{ Ліполітична активність, од.акт/г.тк. } \\
\hline Адаптації після вилуплення & $12,18 \pm 1,51$ & $20,84 \pm 0,91$ & $61,28 \pm 2,01$ \\
\hline Розсмоктування залишкового жовтка & $85,60 \pm 3,71$ & $22,61 \pm 0,74$ & $68,73 \pm 1,78$ \\
\hline Статевої зрілості & $112,73 \pm 3,75$ & $52,44 \pm 2,03$ & $84,18 \pm 2,59$ \\
\hline
\end{tabular}


Водночас, у перепілок, у цей період, активність ензимів була вищою удвічі, а в качок - у дев'ять разів. На час повного розсмоктування залишкового жовтка була найвищою у молодняку перепілок і зростала в послідовності: перепілки, кури, качки. У дорослої статевозрілої птиці послідовність збільшення активності ензимів була іншою, а саме: кури, качки, перепілки.

На першу добу після вилуплення курчат амілолітична активність підшлункової залози була майже в чотири рази нижчою, ніж у перепелят та каченят. У наступні досліджувані вікові періоди, навпаки, амілолітична активність була найвищою у курей і перевищувала показники качок і перепілок.

Щодо ліполітичної активності, то лише у період адаптації після вилуплення птиці вона зростала в послідовності: кури, перепілки, качки. Тоді як в про- цесі повного розсмоктування залишкового жовтка та становлення статевої зрілості найнижчою вона була у перепілок і була нижчою, відповідно, у 3,0 і 3,8 раза, ніж у качок, та в 1,6 і 2,1 раза, ніж у курей.

Печінка бере безпосередню участь у процесах травлення, оскільки у ній синтезується найважливіший травний сік - жовч, яка інактивує пепсин, а також нейтралізує кислий хімус, який поступає зі шлунка, що забезпечує перехід від шлункового до кишкового травлення, активує ензими кишкового і панкреатичного соку, особливо ліпази, а також стимулює секрецію підшлункового і кишкового соків .

Результати наших досліджень свідчать (табл. 4) про те, що протеолітична активність ензимів печінки курей була вищою, ніж у перепілок та качок в усі досліджувані нами вікові періоди.

\section{Таблиця 4}

Видові особливості активності гідролітичних ензимів печінки, $(\mathrm{M} \pm \mathrm{m}, \mathrm{n}=5)$

\begin{tabular}{|c|c|c|c|}
\hline Фізіологічний період & Кури & Перепілки & Качки \\
\hline \multicolumn{4}{|c|}{ Протеолітична активність, мкат/г.б. } \\
\hline Адаптації після вилуплення & $3,50 \pm 0,35$ & $1,69 \pm 0,11$ & $1,61 \pm 0,18$ \\
\hline Розсмоктування залишкового жовтка & $2,82 \pm 0,23$ & $1,92 \pm 0,11$ & $2,04 \pm 0,28$ \\
\hline Статевої зрілості & $2,37 \pm 0,10$ & $1,44 \pm 0,12$ & $1,25 \pm 0,11$ \\
\hline \multicolumn{4}{|c|}{ Амілолітична активність, од.акт/хв ${ }^{\times}$г.білка } \\
\hline Адаптації після вилуплення & $4,45 \pm 0,19$ & $5,32 \pm 0,34$ & $5,35 \pm 0,23$ \\
\hline Розсмоктування залишкового жовтка & $2,74 \pm 0,26$ & $4,71 \pm 0,27$ & $3,25 \pm 0,86$ \\
\hline Статевої зрілості & $4,43 \pm 0,25$ & $5,34 \pm 0,45$ & $5,98 \pm 0,29$ \\
\hline \multicolumn{4}{|c|}{ Ліполітична активність, од.акт/г.тк } \\
\hline Адаптації після вилуплення & $3,21 \pm 0,59$ & $11,56 \pm 0,86$ & $15,53 \pm 0,54$ \\
\hline Розсмоктування залишкового жовтка & $3,72 \pm 0,14$ & $8,99 \pm 0,92$ & $23,25 \pm 0,87$ \\
\hline Статевої зрілості & $5,09 \pm 0,61$ & $9,23 \pm 0,63$ & $15,65 \pm 0,36$ \\
\hline
\end{tabular}

Так, відразу після вилуплення курчат активність переважала показники в інших видів птиці у 2,2 раза, на момент розсмоктування залишкового жовтка - в 1,4 раза і на час статевої зрілості - в 1,8 раза. При цьому, активність протеаз у печінці перепілок та качок була, приблизно на одному рівні.

Щодо амілолітичної активності, то у курей вона буда дещо нижчою, ніж у перепілок і качок у період адаптації після вилуплення та статевої зрілості. Тоді як у період розсмоктування залишкового жовтка вона збільшувалась у такій послідовності: кури, качки, перепілки. Ліполітична активність у печінці, в усі досліджувані фізіологічні періоди розвитку птиці, збільшувалась у такій послідовності: кури, перепілки, качки.

При цьому, відзначимо, що співвідношення активності ліпаз між цими видами птиці було як: 1:3:5 - у період адаптації після вилуплення; 1:3:8 - у період розсмоктування залишкового жовтка; 1:2:3 - із настанням статевої зрілості.

\section{Висновки}

Встановлено, що характер змін активності гідролітичних ензимів мав органо-тканинну та видову специфічність. Це зумовлено не лише особливостями травлення у перепілок, курей та качок, але й енергетичною цінністю раціонів, які використовуються у годівлі кожного виду сільськогосподарської птиці, що суттєво впливає на метаболічні процеси в організмі.

Перспективи подальших досліджень. Перспективним є подальше дослідження дії аліментарних чинників на активність гідролітичних ензимів в органах травного каналу птиці різних видів.

\section{References}

Batoev, Ts.Zh. (2011). Fiziologiya pischevareniya ptits. Ulan-Ude: Izd-vo Buryatskogo gosuniversiteta (in Russian).

Fisinin, V.I., \& Egorov, I.A. (2011). Sovremennyie podhodyi k kormleniyu ptitsyi. Ptitsevodstvo, 3, 7-10 (in Russian).

Hunchak, A.V., Ratych, I.B., Gutyj, B.V., \& Paskevych, H.A. (2016). Metabolic effects of iodine in poultry for its deficiency or excess in the diet. Scientific Messenger LNUVMBT named after S.Z. Gzhytskyj, 18, 2(67), 70-76. doi: 10.15421/nvlvet6716.

Kharchenko, L.P. (2004). Sravnitelnaia kharakteristika pishchevaritelnykh fermentov i domashnikh i dikikh ptits. Ptakhivnytstvo: Mizhvidomchyi tematychnyi zbirnyk. IP UAAN. Kharkiv, 55, 373-379 (in Ukrainian).

Kryshtalska, M., Hunchak, V., \& Gutyj, B. (2017). Influence of the drug "Trifuzol" on the functional state of the liver in chickens for eymeriozic invasion. 
Scientific Messenger LNUVMBT named after S.Z. Gzhytskyj, 19(77), 76-79. doi: 10.15421/nvlvet7718.

Kyryliv, B. (2018). Age dynamics of growth and development of chichens depending on protein metabolism. Scientific Messenger of Lviv National University of Veterinary Medicine and Biotechnologies, 20(84), 131-136. doi: 10.15421/nvlvet8424.

Kyryliv, B.Ia, \& Hunchak, A.V. (2016). Aktyvnist hidrolitychnykh enzymiv orhaniv travnoho traktu kurei v ontohenezi. Visnyk Sumskoho natsionalnoho ahrarnoho universytetu. Seriia "Tvarynnytstvo", 5(29), 170-174 (in Ukrainian).

Kyryliv, B.Ya., \& Hunchak, A.V. (2016). The influence of alimentary factors on productivity hens. Scientific Messenger LNUVMBT named after S.Z. Gzhytskyj, 18, 2(67), 287-291. doi: 10.15421/nvlvet6762.

Medvid, S.M., Hunchak, A.V., Gutyj, B.V., \& Ratych, I.B. (2017). Prospects of rational security chicken-broilers with mineral substances. Scientific Messenger LNUVMB, 19(79), 127-134. doi: 10.15421/nvlvet7925.

Naumenko, V.V., Diachynskyi, A.S., \& Demchenko, V.Iu. (2009). Fiziolohiia silskohospodarskykh tvaryn. K.: Tsentr uchbovoi literatury (in Ukrainian).

Vladimír, P., Lode, N., \& Gabriel, K. (2010). Effect of Dietary Supplementation of Trace Elements on the Growth Performance and Their Distribution in the Breast and Thigh Muscles Depending on the Age of Broiler Chickens. Acta Vet. Brno, 79, 203-209. doi: 10.2754/avb201079020203.

Vlizlo, V.V., Fedoruk, R.S., \& Ratych, I.B. (2012). Laboratory methods of investigation in biology, stockbreeding and veterinary. A reference book. Ed. by VV Vlizlo. Lviv: Spolom (in Ukrainian). 